\title{
Penerapan Fuzzy MADM dalam Penentuan Karyawan Terbaik Berbasis Mobile Android (Studi Kasus: RSI Assyifa Sukabumi)
}

\author{
Saeful Bahri \\ Sistem Informasi, \\ Sekolah Tinggi Manajemen Informatika dan \\ Komputer Nusa Mandiri \\ Jl. Margonda Raya No.545, RW.7, Pondok \\ Cina, Kecamatan Beji, Kota Depok, Jawa Barat \\ 0218005722 \\ saeful.sel@ nusamandiri.ac.id
}

\author{
Rusda Wajhillah, Dasya Arief Firmansyah \\ Program Studi Sistem Informasi, \\ Fakultas Teknik dan Informatika, \\ Universitas BSI Kampus Sukabumi \\ Jalan Cemerlang No 8 Kel Sukakarya Kota \\ Sukabumi, Telp/Fax Institusi \\ rusda.rwh@bsi.ac.id,dasya.daf@bsi.ac.id
}

Diterima: 26 November 2020. Disetujui: 22 Desember 2020. Dipublikasikan: 23 Desember 2020.

\begin{abstract}
The development and progress of each company is always supported by large assets, namely due to the presence of outstanding employees. It takes human resources who have competence, loyalty, discipline and good relationships among employees, in an effort to improve employee performance. The Assyifa Sukabumi Islamic Hospital as one of the hospitals with a large number of employees, still has problems in determining the best employees. Where the selection of employees is still done manually so that the element of subjectivity is relatively high, and requires a relatively long time. It is necessary to use information technology that can be an alternative solution to assist in determining the best employees. In this study, the sample criteria that have been in RSI Assyifa were taken in determining the best employees. These criteria consist of; communication, appreciation, attendance, implementation of duties, running SPO, activeness and achievements. Based on these criteria, weighting and ranking were carried out using the Fuzzy Multiple Attribute Decision Making (MADM) method, in this study the results were obtained in the form of a mobile application that can be used by RSI Assyifa in helping determine the best employee.
\end{abstract}

Keywords: the best employee criteria; fuzzy madm

Abstrak-- Perkembangan dan kemajuan setiap perusahaan selalu ditunjang oleh aset besar yaitu karena adanya karyawan berprestasi. Dibutuhkan sumber daya manusia yang mempunyai kompetensi, loyalitas, kedisiplinan dan hubungan yang baik diantara karyawan, dalam upaya peningkatan kinerja karyawan. Rumah Sakit Islam Assyifa Sukabumi sebagai salah satu rumah sakit dengan jumlah karyawan yang cukup banyak, masih memiliki kendala dalam penentuan karyawan terbaiknya. Dimana pemilihan karyawan masih dilakukan secara manual sehingga unsur subjektifitas relatif tinggi, dan membutuhkan waktu yang relatif lama. Diperlukan pemanfaatan teknologi informasi yang dapat menjadi alternatif solusi guna membantu dalam penentuan karyawan terbaiknya. Pada penelitian ini diambil kriteria sampel yang telah ada di RSI Assyifa dalam penentuan karyawan terbaiknya. Kriteria tersebut terdiri dari; komunikasi, apresiasi, absensi, pelaksanaan tugas, menjalankan SPO, keaktifan dan prestasi yang dimiliki. Berdasar kriteria tersebut kemudian dilakukan pembobotan dan perangkingan menggunakan metode Fuzzy Multiple Atribute Decision Making (MADM), dalam penelitian ini didapat hasil berupa sebuah aplikasi mobile yang dapat digunakan, oleh RSI Assyifa dalam membantu dalam menentukan karyawan terbaiknya.

Kata kunci: kriteria karyawan terbaik; fuzzy madm

\section{PENDAHULUAN}

Karyawan terbaik dan berprestasi akan menjadi aset bagi sebuah perusahaan dan berkontribusi atas kemajuan dan perkembangan perusahaan. Kinerja karyawan akan berpengaruh signifikan terhadap performa perusahaan, baik secara keuntungan atau pelayanan dalam perjalanan usahanya[1]. Diperlukan sumber daya manusia yang mempunyai kompetensi, loyalitas, kedisiplinan dan hubungan yang baik diantara karyawan, dalam upaya peningkatan kinerja karyawan. Beberapa program dalam menstimulus telah dilaksanakan salah satunya adalah dengan pemberian anugrah karyawan terbaik dalam setiap priodenya[2], [3].

Rumah Sakit Islam (RSI) Assyifa Sukabumi sebagai salah satu rumah sakit dengan jumlah karyawan yang cukup banyak, masih memiliki kendala dalam penentuan karyawan terbaiknya. Dimana pemilihan karyawan masih dilakukan secara 
manual sehingga unsur subjektifitas relatif tinggi, dan membutuhkan waktu yang relatif lama. Sehingga diperlukan pemanfaatan teknologi informasi yang dapat menajadi alternatif solusi guna membantu RSI Assyifa dalam penentuan karyawan terbaiknya. Penentuan karyawan terbaik, merupakan salah satu upaya perusahaan untuk menghasilkan calon pemimpin baru yang sesuai dengan kriteria perusahaan. Perusahaan berharap dengan adanya pemilihan karyawan terbaik dapat memotivasi karyawan dalam mengembangkan diri[4] . Penilaian pegawai berprestasi pada Komisi Pemilihan Umum Kabupaten Bogor melalui proses perangkingan yang akan menentukan alternatif yang optimal menggunakan metode SAW [5].

Metode Fuzzy Multiple Atribute Decision Making (MADM) merupakan sebuah metode yang dapat digunakan dalam mencari alternatif optimal dari beberapa alternatif dengan kriteria tertentu. Pada dasarnya Fuzzy MADM adalah menentukan nilai bobot untuk setiap atribut, Fuzzy MADM telah bayak digunakan oleh para peneliti di dunia, penelitian menggunakan Fuzzy MADM telah diterapkan dalam bidang ekonomi, pemerintahan [6]-[8], bidang pendidikan seperti dalam penelitian Sugiarto, dkk., [9] dan beberapa bidang lain. Beberapa penelitian lain seperti penelitian yang dilakukan oleh Wu Bing, dkk., dalam penelitiannya yang membahas tentang pemilihan lokasi penempataan turbin angin, diungkapkan bahwa Fuzzy MADM sangat cocok untuk penentuan dengan kriteria yang banyak[10], [5], [11]. Penelitian lain yang telah sukses menerapkan Fuzzy MADM ialah penelitian yang dilakukann oleh Nugroho, dkk., dalam penelitiannya yang berjudul sistem perekomendasian penggunaan oli, disebutkan bahwa Fuzzy MADM cocok digunakan dalam penentuan dengan kriteria yang beragam sehingga dengan menggunakan Fuzzy proses penentuan keputusan menjadi lebih cepat dan relatif lebih objektif[12].

Proses Fuzzy MADM dimulai dengan cara menetukan kriteria yang digunakan, selanjutnya, perangkingan kemudian proses perangkingan untuk mementukan hasil seleksi alternatif yang telah diberikan. Pencarian alternatif optimal ini secara umum dapat menggunakan algoritma pengambil keputusan lainnya, diantaranya menggunakan Technique for Order Preference by Similarity to Ideal Solution (TOPSIS), Simple Additive Weighting (SAW), Analytic Hierarchy Process (AHP), Weighted Product (WP), ELECTRE.
Pada penelitian ini diambil kriteria sampel yang telah ada di RSI Assyifa dalam penentuan karyawan terbaiknya. Kriteria yang dimaksud terdiri dari; komunikasi, apresiasi, absensi, pelaksanaan tugas, menjalankan SPO, keaktifan dan prestasi yang dimiliki. Berdasar kriteria tersebut kemudian dilakukan pembobotan dan perangkingan menggunakan metode Fuzzy Multiple Atribute Decision Making (MADM).

Model yang diperoleh dari penerapan metode Fuzzy MADM selanjutnya akan diimplementasikan ke dalam program berbasis mobile. Pengembangan sistem pada penelitian ini dilakukan dengan metode Prototype dan diuji menggunakan pengujian white box.

\section{METODE PENELITIAN}

Metode penelitian yang digunakan adalah dengan melakukan observasi, wawancara dan studi literatur, dalam observasi langsung datang untuk mencari data dan melakukan wawancara. Berikut adalah uraian tahapan peneitian yang kami lakukan.

\section{A. Observasi}

Dalam tahapan ini kami sebagai peneliti mengamati proses penentuan karyawan terbaik yang terjadi, observasi ini dimaksudkan untuk menemukan beberapa permasalahan yang ada dalam proses penentuan pemilihan karyawan terbaik di RSI Assyifa.

\section{B. Wawancara}

Setelah kami menemukan permasalahan yang yang terjadi dalam penentuan karyawan terbaik di RSI Assyifa, selanjutnya kami melakukan wawancara kepada pihak yaang berhubungan secara langsung dalam proses penentun karyawan terbaik yaitu Bagian Kepala Sumber Daya dan Manajer Rumah Sakit, wawancara ini bertujuan untuk menemukan atau menentukan model yang paling tepat untuk mengatasi permasahaan dalam proses pemilihan karyawan.

\section{Perancangan Sistem}

Setelah model terbaik dalam penyelesaian masalah ditemukan tahapan selanjutnya kami melakukan perancangan sistem mulai dari penentuan platform yang digunakan, sampai dengan penentuan target pengguna dari mode aplikasi yang dirancang.

Selain metode observasi dan wawancara juga dilakukan studi literatur dengan cara membuat state 
of the art dari beberapa penelitian terdahulu yang melakukan penelitian tentang Fuzzy Multiple Attribute Decission Making disajikan sebagai berikut:

Penelitian yang dilakukan oleh Bernadus Cristoko 2017 yang berjudul Fuzzy Multi-Attribute Decission Making dengan Metode SAW Untuk pemilihan mahasiswa berprestasi dalam penelitiannya menawarkan solusi berupa penggunaan perhitungan Fuzzy Multiple Attribute Decision Making (FMADM) dalam penentuan nilai bobot untuk setiap atribut dan dilakukan proses perangkingan dan menyimpulkan bahwa hasil yang didapat adalah mampu menentukan kriteria siswa berprestasi[13].

Penelitian yang dilakukan oleh Lismardiana pada tahun 2018 yang berjudul Fuzzy Multi Attribut Decision Making dengan metode SAW dalam penentuan lulusan mahasiswa berprestasi dalam penelitiannya menawarkan solusi tentang penentuan kriteria lulusan mahasiswa dengan cara menentukan kriteria terbaik berdasarkan IPK setiap semester[14].

Penelitian yang dilakukan oleh Rismayani dan Rodia pada tahun 2019 dalam penelitian yang berjudul Analisis Fuzzy MADM Menggunakan Metode SAW dalam seleksi calon Karyawan PT. Teknorina Cipta Karya yang memberikan solusi berupa pengembangan sebuah model pemilihan karyawan dengan Fuzzy MADM dan SAW sehingga perusahaan menjadi lebih objektif dalam penentuan pemilihan karyawan[4].

Penelitian yang dilakukan oleh Abdullah Muhazzir pada tahun 2019 yang berjudul Sistem Pendukung Keputusan Pemilihan Smartphone Android Menggunakan Metode Fuzzy dalam penelitian tersebut solusi yang diberikan adalah dengan cara penerapan metode Fuzzy yang bekerja dengan cara mengubah kriteria komponen smartphone yang digunakan dalam pemilihan varian menjadi inferensi. Hasil dari penelitian ini adalah keputusan yang diberikan sudah sesuai dengan rancangan, di mana hasil keputusan yang diberikan adalah varian smartphone terbaik yang sesuai dengan nilai budget yang diinputkan pengguna[15].

Berdasar state of the art di atas, model dari Fuzzy MADM yang diperoleh akan diterapkan ke dalam aplikasi berbasis mobile.

\section{HASIL DAN PEMBAHASAN}

Pada bagian ini akan dijelaskan proses pembangunan model Fuzzy MADM yang kemudian nantinya akan dimplementasikan ke dalam bentuk bahasa pemrograman yang berbasis mobile application. Berikut ini merupakan proses pengolahan dan pembentukan model:

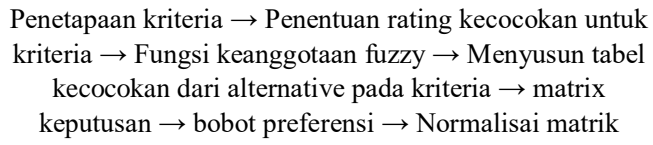

Penetapaan kriteria $\rightarrow$ Penentuan rating kecocokan untuk kriteria $\rightarrow$ Fungsi keanggotaan fuzzy $\rightarrow$ Menyusun tabel kecocokan dari alternative pada kriteria $\rightarrow$ matrix keputusan $\rightarrow$ bobot preferensi $\rightarrow$ Normalisai matrik

\section{A. Penetapan Kriteria}

Agar diperoleh nilai yang baku pada proses perhitungan matriks selanjutnya, maka diperlukan tahapan penetapan nilai kriteria dan penentuan rating kecocokan untuk setiap kriteria. Dapat dilihat pada rincian Tabel I.

TABEL I. KRITERIA

\begin{tabular}{|c|l|}
\hline Kriteria & Keterangan \\
\hline C1 & Komunikasi Baik \\
\hline C2 & Apresiasi Khusus \\
\hline C3 & Absensi Kehadiran \\
\hline C4 & Melakasanakan Sesuai Tugas dengan baik \\
\hline C5 & $\begin{array}{l}\text { Menjalanakan SPO yang ada diunit kerja dengan } \\
\text { baik }\end{array}$ \\
\hline C6 & Aktif dalam kegiatan rumah sakit \\
\hline C7 & Memiliki prestasi dan mengangkat rumah sakit \\
\hline
\end{tabular}

Dalam Tabel I dapat diuraikan beberapa kriteria seperti komunikasi baik, merupakan cara komunikasi antar karyawan dan pimpinan di lingkungan perusahaan. Apresiasi khusus merupakan sebuah penghargaan dari rekan atau unit pimpinan dimana karyawan tersebut ditempatkan. Melaksanakan sesuai tugas dengan baik merupakan kemampuan seorang karyawan dalam melaksanakan tugas dengan baik dan tepat. Melaksanakan SPO yang ada di unit kerja dengan baik merupakan capaian karyawan dalam mengerjakan pekerjaan sesuai standar yang ada. Aktif dalam kegiatan rumah sakit merupakan sebuah aktivitas karyawan di luar pekerjaan utama karyawan itu sendiri misalnya menjadi pengurus masjid dan organisasi internal perusahaan. Memiliki prestasi dan mengangkat rumah sakit merupakan prestasi yang didapat karyawan di luar maupun di dalam lingkungan rumah sakit misalnya seperti mendapatkan anugrah inovasi rumah sakit.

Setelah beberapa kriteria yang dibutuhkan kemudian kriteria tersebut diberikan nilai sesuai dengan nilai kepentingannya berikut bobot kriteria 
yang digunakan, diuraikan dalam Tabel II sampai dengan Tabel XI, sedangkan pada Tabel XII dan Tabel XIII merupakan hasil pemberian kriteria yang akan digunakan dalam tahapan berikutnya.

TABEL II. BOBOT KRITERIA

\begin{tabular}{|c|c|}
\hline Bilangan Fuzzy & Nilai \\
\hline Tidak penting & 1 \\
\hline Kurang penting & 2 \\
\hline Cukup penting & 3 \\
\hline Penting & 4 \\
\hline Sangat penting & 5 \\
\hline
\end{tabular}

TABEL III. BOBOT KOMUNIKASI

\begin{tabular}{|c|c|}
\hline Bilangan Fuzzy & Nilai \\
\hline Buruk & 1 \\
\hline Kurang baik & 2 \\
\hline Cukup Baik & 3 \\
\hline Baik & 4 \\
\hline Sangat Baik & 5 \\
\hline
\end{tabular}

TABEL IV. BOBOT APRESIASI KHUSUS

\begin{tabular}{|c|c|}
\hline Bilangan Fuzzy & Nilai \\
\hline Rendah & 1 \\
\hline Sedang & 2 \\
\hline Tinggi & 3 \\
\hline
\end{tabular}

TABEL V. BOBOT KRITERIA

\begin{tabular}{|c|c|}
\hline Bilangan Fuzzy & Nilai \\
\hline$<1$ & 5 \\
\hline $2-5$ & 4 \\
\hline $5-7$ & 3 \\
\hline $7-10$ & 2 \\
\hline$>10$ & 1 \\
\hline
\end{tabular}

TABEL VI. BOBOT MELAKSANAKAN TUGAS

\begin{tabular}{|l|c|}
\hline Bilangan Fuzzy & Nilai \\
\hline Buruk & 1 \\
\hline Kurang baik & 2 \\
\hline Cukup Baik & 3 \\
\hline Baik & 4 \\
\hline Sangat Baik & 5 \\
\hline
\end{tabular}

TABEL VII. BOBOT SPO

\begin{tabular}{|c|c|}
\hline Bilangan Fuzzy & Nilai \\
\hline Buruk & 1 \\
\hline Kurang baik & 2 \\
\hline Cukup Baik & 3 \\
\hline Baik & 4 \\
\hline Sangat Baik & 5 \\
\hline
\end{tabular}

TABEL VIII. BOBOT AKTIF DALAM RUMAH SAKIT

\begin{tabular}{|c|c|}
\hline Bilangan Fuzzy & Nilai \\
\hline Tidak Aktif & 1 \\
\hline Kurang Aktif & 2 \\
\hline Cukup Aktif & 3 \\
\hline Aktif & 4 \\
\hline Sangat Aktif & 5 \\
\hline
\end{tabular}

TABEL IX. BOBOT PRESTASI

\begin{tabular}{|c|c|}
\hline Bilangan Fuzzy & Nilai \\
\hline$<1$ & 1 \\
\hline $1-2$ & 2 \\
\hline $2-3$ & 3 \\
\hline $3-5$ & 4 \\
\hline$>5$ & 5 \\
\hline
\end{tabular}

TABEL X. VEKTOR BOBOT W

\begin{tabular}{|c|c|}
\hline Kriteria & Nilai \\
\hline C1 (Komunikasi) & 2 \\
\hline C2 (apresiasi khusus) & 3 \\
\hline C3(absensi) & 5 \\
\hline C4(melaksanakan tugas) & 4 \\
\hline C5(menjalankan SPO) & 5 \\
\hline C6(aktif) & 4 \\
\hline C7(prestasi) & 4 \\
\hline
\end{tabular}

TABEL XI. PERHITUNGAN FUZZY MADM

\begin{tabular}{|c|c|}
\hline Kriteria & Kriteria Terbaik \\
\hline C1 (Komunikasi) & Cukup baik \\
\hline C2 (apresiasi khusus) & Sedang \\
\hline C3(absensi) & $<1$ \\
\hline C4(melaksanakan tugas) & Baik \\
\hline C5(menjalankan SPO) & Cukup Baik \\
\hline C6(aktif) & Sangat Aktif \\
\hline C7(prestasi) & $1-2$ \\
\hline
\end{tabular}

TABEL XII. KRITERIA KARYAWAN TERBAIK

\begin{tabular}{|c|c|c|c|c|}
\hline Kriteria & $\begin{array}{c}\text { Karya- } \\
\text { wan 1 }\end{array}$ & $\begin{array}{c}\text { Karya- } \\
\text { wan 2 }\end{array}$ & $\begin{array}{c}\text { Karya- } \\
\text { wan 3 }\end{array}$ & $\begin{array}{c}\text { Karya- } \\
\text { wan 4 }\end{array}$ \\
\hline C1 & $\begin{array}{c}\text { Cukup } \\
\text { baik }\end{array}$ & Baik & $\begin{array}{c}\text { Sangat } \\
\text { Baik }\end{array}$ & $\begin{array}{c}\text { Sangat } \\
\text { Baik }\end{array}$ \\
\hline C2 & Sedang & Rendah & Rendah & sedang \\
\hline C3 & $<1$ & $2-5$ & $<1$ & $2-5$ \\
\hline C4 & Baik & $\begin{array}{c}\text { Sangat } \\
\text { Baik }\end{array}$ & $\begin{array}{c}\text { Kurang } \\
\text { Baik }\end{array}$ & Baik \\
\hline C5 & $\begin{array}{c}\text { Cukup } \\
\text { Baik }\end{array}$ & Baik & $\begin{array}{c}\text { Kurang } \\
\text { Baik }\end{array}$ & Baik \\
\hline C6 & $\begin{array}{c}\text { Sangat } \\
\text { Aktif }\end{array}$ & Aktif & Aktif & Aktif \\
\hline C7 & $1-2$ & $2-3$ & $<1$ & $3-5$ \\
\hline
\end{tabular}

TABEL XIII. BOBOT PREFERENSI

\begin{tabular}{|c|c|c|c|c|c|c|c|c|}
\hline \multirow[b]{2}{*}{$\begin{array}{c}\text { ALTERNA } \\
\text { TIF }\end{array}$} & \multicolumn{8}{|c|}{ KRITERIA } \\
\hline & $\begin{array}{l}\mathrm{C} \\
\mathbf{1}\end{array}$ & C & $\begin{array}{l}\mathrm{C} \\
3\end{array}$ & $\begin{array}{l}\mathrm{C} \\
4\end{array}$ & $\begin{array}{l}\mathbf{C} \\
\mathbf{5}\end{array}$ & $\begin{array}{l}\mathrm{C} \\
6\end{array}$ & $\begin{array}{l}\text { C } \\
7\end{array}$ & $\begin{array}{c}\text { JUML } \\
\mathbf{A H}\end{array}$ \\
\hline Karyawan 1 & 3 & 2 & 5 & 4 & 3 & 5 & 2 & 24 \\
\hline Karyawan 2 & 4 & 2 & 4 & 5 & 4 & 4 & 3 & 26 \\
\hline Karyawan 3 & 5 & 1 & 5 & 2 & 2 & 4 & 1 & 20 \\
\hline Karyawan 4 & 5 & 2 & 4 & 4 & 4 & 4 & 4 & 27 \\
\hline $\begin{array}{l}\text { Kriteria } \\
\text { Terbaik }\end{array}$ & 3 & 2 & 5 & 4 & 3 & 5 & 2 & 24 \\
\hline
\end{tabular}


Matrik keputusan yang terbentuk sebagai berikut:

$$
x_{\text {karyawan }}=\left\{\begin{array}{c}
3,2,5,4,3,5,3 \\
4,2,4,5,4,4,3 \\
5,1,5,2,2,4,1 \\
5,2,4,4,4,4,4 \\
\mathbf{3 , 2 , 5 , 4 , 3 , 5 , 2}
\end{array}\right.
$$

$\mathrm{X}$ kriteria terbaik $=\{3,2,5,4,3,5,2\}$

Langkah selanjutnya adalah normalisasi sebagai berikut:

$$
\begin{aligned}
& \text { Karyawan 1: } \\
& \mathrm{r} 11=\frac{3}{\max (3,4,5,5)}=\frac{3}{4}=0,75 \\
& \mathrm{r} 12=\frac{2}{\max (2,2,1,2)}=\frac{2}{2}=1 \\
& \mathrm{r} 13=\frac{5}{\max (5,4,5,4)}=\frac{5}{5}=1 \\
& \mathrm{r} 14=\frac{4}{\max (4,5,2,4)}=\frac{4}{5}=0,8 \\
& \mathrm{r} 15=\frac{3}{\max (3,4,2,4)}=\frac{3}{4}=0,75 \\
& \mathrm{r} 16=\frac{5}{\max (5,4,4,4)}=\frac{5}{5}=1 \\
& \mathrm{r} 17=\frac{3}{\max (3,3,1,4)}=\frac{3}{4}=0,75
\end{aligned}
$$

\section{Karyawan 2:}

$$
\begin{aligned}
& \mathrm{r} 21=\frac{4}{\max (3,4,5,5)}=\frac{4}{5}=0,8 \\
& \mathrm{r} 22=\frac{2}{\max (2,2,1,2)}=\frac{2}{2}=1 \\
& \mathrm{r} 23=\frac{4}{\max (5,4,5,4)}=\frac{4}{5}=0,8 \\
& \mathrm{r} 24=\frac{5}{\max (4,5,2,4)}=\frac{5}{5}=1 \\
& \mathrm{r} 25=\frac{4}{\max (3,4,2,4)}=\frac{4}{4}=1 \\
& \mathrm{r} 26=\frac{4}{\max (5,4,4,4)}=\frac{4}{5}=0,8 \\
& \mathrm{r} 27=\frac{3}{\max (3,3,1,4)}=\frac{3}{4}=0,75
\end{aligned}
$$

\section{Karyawan 3:}

$$
\begin{aligned}
& \mathrm{r} 31=\frac{5}{\max (3,4,5,5)}=\frac{5}{5}=1 \\
& \mathrm{r} 32=\frac{1}{\max (2,2,1,2)}=\frac{1}{2}=0,5 \\
& \mathrm{r} 33=\frac{5}{\max (5,4,5,4)}=\frac{5}{5}=1 \\
& \mathrm{r} 34=\frac{2}{\max (4,5,2,4)}=\frac{2}{5}=0,4 \\
& \mathrm{r} 35=\frac{2}{\max (3,4,2,4)}=\frac{2}{4}=0,5 \\
& \mathrm{r} 36=\frac{4}{\max (5,4,4,4)}=\frac{4}{5}=0,8 \\
& \mathrm{r} 37=\frac{1}{\max (3,3,1,4)}=\frac{1}{4}=0,25
\end{aligned}
$$

\section{Karyawan 4:}

$$
\begin{aligned}
& \mathrm{r} 41=\frac{5}{\max (3,4,5,5)}=\frac{5}{5}=1 \\
& \mathrm{r} 42=\frac{2}{\max (2,2,1,2)}=\frac{2}{2}=1
\end{aligned}
$$

$$
\begin{aligned}
& \mathrm{r} 43=\frac{4}{\max (5,4,5,4)}=\frac{4}{5}=0,8 \\
& \mathrm{r} 44=\frac{4}{\max (4,5,2,4)}=\frac{4}{5}=0,8 \\
& \mathrm{r} 45=\frac{4}{\max (3,4,2,4)}=\frac{4}{4}=1 \\
& \mathrm{r} 46=\frac{4}{\max (5,4,4,4)}=\frac{4}{5}=0,8 \\
& \mathrm{r} 47=\frac{4}{\max (3,3,1,4)}=\frac{4}{4}=1
\end{aligned}
$$

Bobot kriteria karyawan terbaik:

$$
\begin{aligned}
& \mathrm{r} 11=\frac{3}{\max (3,4,5,5)}=\frac{3}{5}=0,6 \\
& \mathrm{r} 12=\frac{2}{\max (2,2,1,2)}=\frac{2}{2}=1 \\
& \mathrm{r} 13=\frac{5}{\max (5,4,5,4)}=\frac{5}{5}=1 \\
& \mathrm{r} 14=\frac{4}{\max (4,5,2,4)}=\frac{4}{5}=0,8 \\
& \mathrm{r} 15=\frac{5}{\max (3,4,2,4)}=\frac{5}{4}=1,25 \\
& \mathrm{r} 16=\frac{5}{\max (5,4,4,4)}=\frac{5}{5}=1 \\
& \mathrm{r} 17=\frac{2}{\max (3,3,1,4)}=\frac{2}{4}=0,5
\end{aligned}
$$

Selanjutnya, normalisasi nilai $\mathrm{R}$ yang diperoleh dari hasil normalisasi (x) sebagai berikut:

R karyawan $=\left\{\begin{array}{ccccccc}0,75 & 1 & 1 & 0,8 & 0,75 & 1 & 0,75 \\ 0,8 & 1 & 0,8 & 1 & 1 & 0,8 & 0,75 \\ 1 & 0,5 & 1 & 0,4 & 0,5 & 0,8 & 0,25 \\ 1 & 1 & 0,8 & 0,8 & 1 & 0,8 & 1\end{array}\right.$

R kriteria karyawan terbaik $=\{0,6 ; 1 ; 1 ; 0,8 ; 1,25 ; 1$; $0,5\}$

Selanjutnya akan dibuat perkalian $\mathrm{W} * \mathrm{R}$ dan penjumlahan hasil perkalian untuk memperoleh alternatif terbaik dengan melakukan perankingan nilai terbesar sebagai berikut:

$\mathrm{V}$ karyawan $1=(0,75 * 2)+(1 * 3)+(1 * 5)+(0,8 * 4)$ $+(0,75 * 5)+(1 * 4)+(0,75 * 4)=23,45$

V karyawan $2=(0,8 * 2)+(1 * 3)+(0,8 * 5)+(1 * 4)+$ $(1 * 5)+(0,8 * 4)+(0,75 * 4)=23,8$

V karyawan $3=(1 * 2)+(0,5 * 3)+(1 * 5)+(0,4 * 4)+$ $(0,5 * 5)+(0,8 * 4)+(0,25 * 4)=16,8$

V karyawan4 $=(1 * 2)+(1 * 3)+(0,8 * 5)+(0,8 * 4)+$ $(1 * 5)+(0,8 * 4)+(1 * 4)=24,4$

V kriteria terbaik $=(0,6 * 2)+(1 * 3)+(1 * 5)+(0,8 * 4)$ $+(1,25 * 5)+(1 * 4)+(0,5 * 4)=24,65$

Untuk menentukan karyawan yang sesuai dengan kriteria yang telah ditentukan, hitung selisih semua Vkaryawan dengan Vkualitas karyawan, karyawan yang sesuai yaitu yang selisihnya paling mendekati Vkualifikasi karyawan, yaitu: 
$\mathrm{V}=$ Vkaryawan-Vkualifikasi karyawan

Vkaryawan $1 \quad: 23,45-24,65=-1,2$

Vkaryawan $2: 23,8-24,65=-0,85$

Vkaryawan $3: 16,8-24,65=-7,85$

Vkaryawan4 $: 24,4-24,65=-0,25$

Dari hasil perangkingan dengan melihat nilai terbesar, alternatif V karyawan 4 dengan hasil akhir $-0,25$ adalah alternatif yang terpilih sebagai alternatif terbaik.

\section{B. Implementasi}

Dari model perhitungan yang telah diuraikan di atas maka pada tahap ini akan dilanjutkan dengan proses implementasi ke dalam aplikasi menggunakan platform Android. Pada Gambar 1 (a)(d) merupakan bentuk tampilan dari hasil rancang bangun aplikasi penentuan karyawan terbaik menggunakan Fuzzy MADM.

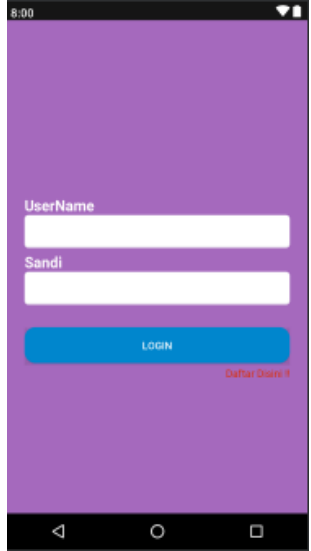

(a)

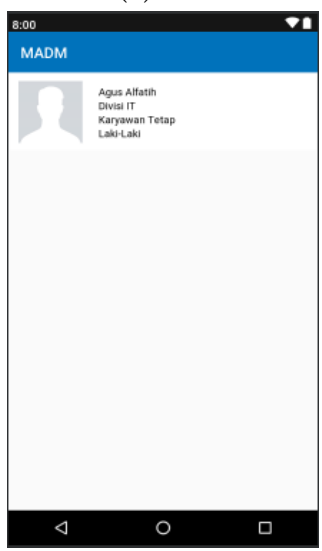

(c)

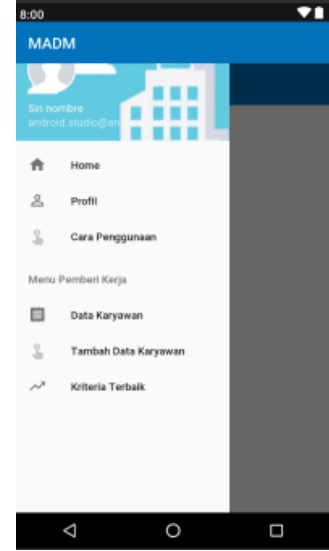

(b)

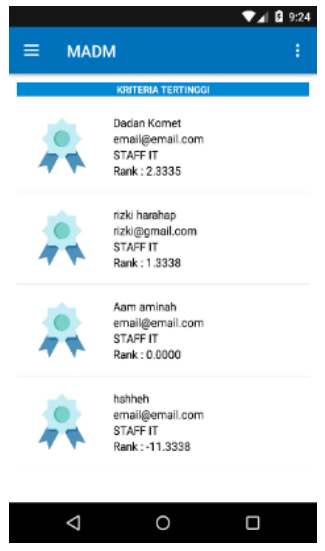

(d)
Gambar 1. (a)Login; (b)Menu Utama; (c) Data Karyawan; (d) Hasil Kriteria

\section{Pengujian}

Pada penelitian ini akan dilakukan pengujian terhadap detail dari sistem yang dirancang menggunakan teknik whitebox testing. Berikut adalah hasil pengujian white box dari beberapa struktur kontrol dari sistem yang dirancang.

Pseudocode pemberian kriteria:

public kriteria (int qmax)

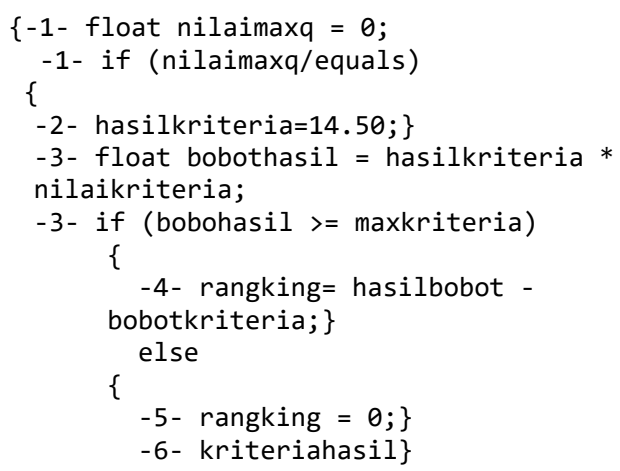

Pada Gambar 2 merupakan bentuk dari Flowgraph dari pseudocode pemberian kriteria di atas.

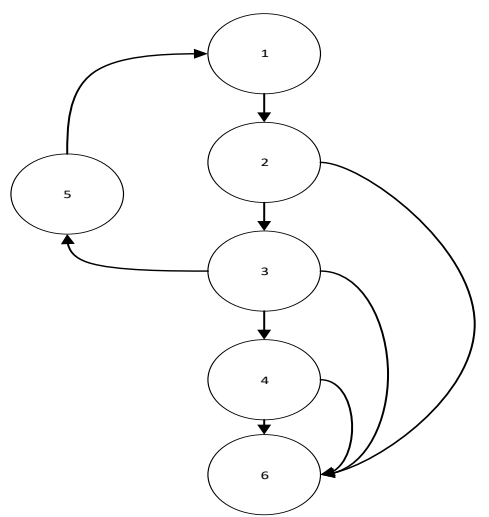

Gambar 2. Pseudocode Pemberian Kriteria

Cyclomatic complecity

$$
\begin{aligned}
\mathrm{V}(\mathrm{G}) & =\mathrm{E}-\mathrm{N}+2 \\
& =9-6+2 \\
& =5
\end{aligned}
$$

Independent path

Path $1=1-2-3-4-6$

Path $2=1-2-6$

Path $3=1-2-3-6$

Path $4=1-5-3$

Path $5=1-2-3-6$ 
Setelah diuraikan tahapan-tahapan dari proses pengujian unit dengan white box testing, maka didapat 5 testcase yang harus disiapkan dalam proses pengujiannya. Testcase yang telah disiapkan dalam skenario pengujian perangkat lunak dapat dilihat pada Tabel XV dibawah ini:

TABEL XIV. HASIL PENGUJIAN UNIT

\begin{tabular}{|c|c|c|c|c|c|}
\hline No & o Path & $\begin{array}{l}\text { Data } \\
\text { Input }\end{array}$ & $\begin{array}{l}\text { Hasil yang } \\
\text { diharapkan }\end{array}$ & Hasil & Status \\
\hline 1 & $\begin{array}{l}1-2-3- \\
4-6\end{array}$ & $\begin{array}{l}\text { Memasuk } \\
\text { an Nilai } \\
\text { qmax, } \\
\text { hasil nilai } \\
\text { kriteria, } \\
\text { bobothasi } \\
\text { l, } \\
\text { rangking, } \\
\text { hasilrang } \\
\text { king, } \\
\text { kriteriaha } \\
\text { sil }\end{array}$ & $\begin{array}{l}\text { Hasil } \\
\text { rangking } \\
\text { muncul sesuai } \\
\text { kriteria yang } \\
\text { diberikan }\end{array}$ & $\begin{array}{l}\text { Rang- } \\
\text { king } \\
\text { muncul } \\
\text { dalam } \\
\text { list }\end{array}$ & Valid \\
\hline 2 & $1-2-6$ & $\begin{array}{l}\text { Memasuk } \\
\text { an Nilai } \\
\text { qmax, } \\
\text { hasil nilai } \\
\text { kriteria, } \\
\text { tidak } \\
\text { memasuk } \\
\text { an } \\
\text { bobothasi } \\
\text { 1, } \\
\text { rangking, } \\
\text { hasilrang } \\
\text { king, } \\
\text { kriteriaha } \\
\text { sil }\end{array}$ & $\begin{array}{l}\text { Hasil rangkin } \\
\text { tidak muncul }\end{array}$ & $\begin{array}{l}\text { Rangki } \\
\text { ng dan } \\
\text { daftar } \\
\text { nama } \\
\text { kosong }\end{array}$ & Valid \\
\hline 3 & $1-2-3-6$ & $\begin{array}{l}\text { Memasuk } \\
\text { an Nilai } \\
\text { qmax, } \\
\text { hasil nilai } \\
\text { kriteria, } \\
\text { bobot } \\
\text { hasil, } \\
\text { tidak } \\
\text { memasuk } \\
\text { an } \\
\text { rangking, } \\
\text { memasuk } \\
\text { an } \\
\text { hasilrang } \\
\text { king, } \\
\text { kriteriaha } \\
\text { sil }\end{array}$ & $\begin{array}{l}\text { Hasil rangkin } \\
\text { tidak muncul }\end{array}$ & $\begin{array}{l}\text { Rangki } \\
\text { ng dan } \\
\text { daftar } \\
\text { nama } \\
\text { kosong }\end{array}$ & Valid \\
\hline 4 & $1-5-3$ & $\begin{array}{l}\text { Memasuk } \\
\text { an Nilai } \\
\text { qmax, } \\
\text { tidak } \\
\text { memasuk } \\
\text { an hasil } \\
\text { nilai } \\
\text { kriteria, } \\
\text { bobot } \\
\text { hasil, }\end{array}$ & $\begin{array}{l}\text { Hasil rangkin } \\
\text { tidak muncul }\end{array}$ & $\begin{array}{l}\text { Rangki } \\
\text { ng dan } \\
\text { daftar } \\
\text { nama } \\
\text { kosong }\end{array}$ & Valid \\
\hline
\end{tabular}

\begin{tabular}{|l|l|l|l|l|l|}
\hline & $\begin{array}{l}\text { rangking, } \\
\text { memasuk } \\
\text { an } \\
\text { hasilrang } \\
\text { king, } \\
\text { kriteriaha } \\
\text { sil }\end{array}$ & & & \\
\hline 5 & $1-2-3-6$ & $\begin{array}{l}\text { Nilaiq } \\
\text { max, } \\
\text { hasilnor } \\
\text { malisasi, } \\
\text { bobot } \\
\text { nilai }\end{array}$ & $\begin{array}{l}\text { Hasil rangkin } \\
\text { tidak muncul }\end{array}$ & $\begin{array}{l}\text { Rangki } \\
\text { ng dan } \\
\text { daftar } \\
\text { nama } \\
\text { kosong }\end{array}$ & Valid \\
\hline & & & \\
\hline
\end{tabular}

\section{KESIMPULAN DAN SARAN}

Dari hasil pengujian perangkat lunak yang dihasilkan dengan metode white box testing dapat disimpulkan bahwa perangkat lunak yang dikembangkan sudah cukup baik hal ini didasarkan pada hasil pengujian unit yang dilakukan pada setiap test case yang divalidasi menunjukan hasil yang valid.

Dengan demikian, software yang dihasilkan dari penelitian ini dapat langsung digunakan oleh pihak RSI Assyifa dalam membantu menentukan karyawan terbaiknya.

Untuk penelitian selanjutnya dapat dikembangkan dengan penambahan kriteria yang telah diberikan bobot terlebih dahulu. Alternatif metode yang digunakan dapat menggunakan SAW (Simple Additive Weight) maupun pembobotanpembobotan lain yang lebih baik.

\section{REFERENSI}

[1] H. Hertyana, "Sistem Pendukung Keputusan Penentuan Karyawan Terbaik Menggunakan Metode Topsis . Jurnal Ilmu Pengetahuan Dan Teknologi Komputer," J. ILMU Pengetah. DAN Teknol. Komput., vol. 4, no. 1, pp. 43-48, 2018.

[2] Rumah Sakit Islam Assyifa, "Pemilihan Karyawan Terbaik," 2020.

[3] Y. Malau, "SISTEM PENDUKUNG KEPUTUSAN PEMILIHAN PEGAWAI BERPRESTASI DI KOMISI PEMILIHAN UMUM KABUPATEN BOGOR," Tek. Komput., vol. 4, no. 1, pp. 66-73, 2018.

[4] R. Rismayuni, "ANALISIS FUZZYMADM MENGGUNAKAN METODE SAWDALAM SELEKSI CALON KARYAWAN PT TEKNORIA CIPTA KARYA," J. Ilm. Teknol. dan Rekayasa, vol. 24, no. 10, p. $21,2019$.

[5] U. Nugroho, Basuki Rahmat, Kridalaksana, Awang Harsa, Haviluddin, "Penerapan Fuzzy Multiple Attribute Decision Making (FMADM) Berbasis Metode Simple Additive Weighting (SAW) Dalam Pemilihan Mobil Bekas," 2018.

[6] B. Wu, T. L. Yip, L. Xie, and Y. Wang, "A fuzzy-MADM based approach for site selection of offshore wind farm in busy waterways in China," Ocean Eng., vol. 168, no. July, 
pp. 121-132, 2018, doi: 10.1016/j.oceaneng.2018.08.065

[7] O. M. Olabanji and K. Mpofu, "Decision analysis for optimal design concept: Hybridized fuzzified weighted decision matrix and fuzzy TOPSIS using design for $\mathrm{X}$ tools," Procedia CIRP, vol. 84, pp. 434-441, 2019, doi: 10.1016/j.procir.2019.04.323.

[8] S. Suhada, T. Hidayatulloh, and S. Fatimah, "Penerapan Fuzzy MADM Model Weighted Product dalam Pengambilan Keputusan Kelayakan Penerimaan Kredit di BPR Nusamba Sukaraja ( The Application of Fuzzy MADM Model Weighted Product in Decisions Support of Credit Worthiness in the BPR Nusamba Sukaraja )," $e$ ISSN : 2579-9801, vol. VI, pp. 61-71, 2018, [Online]. Available:

http://jurnalnasional.ump.ac.id/index.php/JUITA/article/vi ew/2517.

[9] A. W. Sugiyarto, R. Pamungkas, A. R. Rasjava, and A. M. Abadi, "Fuzzy Multi Attribute Decision Making (FMADM) Implementation for Classifying Student's Single Tuition Fee (UKT) Based on Android Applications," J. Phys. Conf. Ser., vol. 1397, no. 1, pp. 412, 2019, doi: 10.1088/1742-6596/1397/1/012061.

[10] A. Hafiz and M. Ma'mur, "Sistem Pendukung Keputusan Pemilihan Karyawan terbaik dengan Pendekatan Weightedproduct," Cendikia, vol. 16, no. 1, pp. 23-28, 2018, [Online]. Available: https://jurnal.dcc.ac.id/index.php/JC/article/view/60.
[11] M. T. Lu, J. F. Tsai, S. P. Shen, M. H. Lin, and Y. C. Hu, "Estimating sustainable development performance in the electrical wire and cable industry: Applying the integrated fuzzy MADM approach," J. Clean. Prod., vol. 277, p. 122440, 2020, doi: 10.1016/j.jclepro.2020.122440.

[12] A. K. Nugroho, I. Permadi, and A. Hanifa, "Sistem Pendukung Keputusan Perekomendasian Oli Menggunakan Fuzzy Madm," J. Nas. Pendidik. Tek. Inform., vol. 9, no. 1, p. 63, 2020, doi: 10.23887/janapati.v9i1.22959.

[13] H. N. Christoko, Bernadus, Indriyawati, Henny, "FUZZY MULTI-ATRIBUTE DECISION MAKING (FUZZY MADM) DENGAN METODE SAW UNTUK PEMILIHAN MAHASISWA BERPRESTASI," Transformatika, vol. 14, no. 1, 2017.

[14] Lismardiana, "FUZZY MULTI-ATRIBUTE DECISION MAKING (FUZZY MADM)DENGAN METODE SAW DALAM PENENTUAN LULUSAN MAHASISWA BERPRESTASI," Teknol. Inf. Dan Komun., vol. 7, no. 1, 2018.

[15] R. F. Muhazir, Abdullah, "system pendukukung keputusan pemeilihan smartphone android menggunakan metode fuzzy," Bul. Utama Tek., vol. 14, no. 3, 2019. 